\title{
Cardiac dyssynchrony : structural, functional, transcriptional and pharmacological aspects
}

Citation for published version (APA):

van Middendorp, L. B. (2015). Cardiac dyssynchrony : structural, functional, transcriptional and pharmacological aspects. [Doctoral Thesis, Maastricht University]. Datawyse / Universitaire Pers Maastricht. https://doi.org/10.26481/dis.20150904lm

Document status and date:

Published: 01/01/2015

DOI:

10.26481/dis.20150904lm

Document Version:

Publisher's PDF, also known as Version of record

\section{Please check the document version of this publication:}

- A submitted manuscript is the version of the article upon submission and before peer-review. There can be important differences between the submitted version and the official published version of record.

People interested in the research are advised to contact the author for the final version of the publication, or visit the DOI to the publisher's website.

- The final author version and the galley proof are versions of the publication after peer review.

- The final published version features the final layout of the paper including the volume, issue and page numbers.

Link to publication

\footnotetext{
General rights rights.

- You may freely distribute the URL identifying the publication in the public portal. please follow below link for the End User Agreement:

www.umlib.nl/taverne-license

Take down policy

If you believe that this document breaches copyright please contact us at:

repository@maastrichtuniversity.nl

providing details and we will investigate your claim.
}

Copyright and moral rights for the publications made accessible in the public portal are retained by the authors and/or other copyright owners and it is a condition of accessing publications that users recognise and abide by the legal requirements associated with these

- Users may download and print one copy of any publication from the public portal for the purpose of private study or research.

- You may not further distribute the material or use it for any profit-making activity or commercial gain

If the publication is distributed under the terms of Article $25 \mathrm{fa}$ of the Dutch Copyright Act, indicated by the "Taverne" license above, 


\section{Cardiac Dyssynchrony}

structural, functional, transcriptional and pharmacological aspects

Linkerbundeltak blok maakt het mogelijk om in vivo onderscheid te maken tussen de effecte van lokale mechanische belasting en neurohumorale factoren op hypertrofie.

(dit proefschrift, hoofdstuk 5 \& 6)

De expressie van MicroRNA-133a en CTGF staan onder invloed van lokale mechanische belasting en leiden tot lokale hypertrofie, zelfs in harten met ernstige volume overbelasting. (dit proefschrift, hoofdstuk 5 \& 6)

MicroRNA-29c en microRNA-30c hebben een anti-fibrotisch effect in harten met geïsoleerd linkerbundeltakblok, maar dit effect wordt teniet gedaan wanneer er zich ook hartfalen ontwikkelt. (dit proefschrift, hoofdstuk 5 \& 6)

Vernakalant is niet atriaal specifiek en lijkt in zijn werking sterk op Flecainide.

(dit proefschrift, hoofdstuk 8)

Ejectiefractie wordt blindelings als maat voor de cardiale functie gebruikt, ondanks dat deze misleidend stabiel kan zijn in harten met klepinsufficiënties en in diastolisch hartfalen.

Het is niet moeilijk om te leren wanneer een hartoperatie geïndiceerd is, het duurt je hele leven om te leren wanneer niet te opereren.

De aaibaarheid en economische waarde van een proefdier zijn negatief gecorreleerd met het aantal proefdieren dat een onderzoeker nodig denkt te hebben om statistisch significante resultaten te boeken.

CNA35 heeft de potentie om gebruikt te worden als marker voor in vivo detectie van diffuse cardiale fibrose.

(Valorisatie)

An apple a day keeps the doctor away... especially if you aim carefully.

(Sir Winston Churchill)

Menigeen vindt zijn hart pas als hii zijn hoofd heeft verloren.

(Nietzsche)

Het is beter één mijl te reizen dan om duizend boeken te lezen.

(Confucius) 